\title{
PENERAPAN MODEL PEMBELAJARAN INKUIRI TERBIMBING UNTUK MENINGKATKAN AKTIVITAS MATEMATIKA PESERTA DIDIK KELAS VII SMP NEGERI 2 KOTA BENGKULU
}

\author{
Rahmi Maiyunda Sari ${ }^{1}$, Rusdi ${ }^{2}$, Della Maulidiya ${ }^{3}$ \\ 1,2,3 Program Studi Pendidikan Matematika, FKIP Universitas Bengkulu \\ email : ${ }^{1}$ rahmimaiyundasari1717@gmail.com, ${ }^{2}$ rusdipendmat12@gmail.com, \\ 3della.maulidiya@unib.ac.id
}

\begin{abstract}
ABSTRAK
Penelitian ini bertujuan untuk mengetahui cara penerapan model inkuiri terbimbing sehingga dapat meningkatkan aktivitas belajar peserta didik kelas VII A SMP Negeri 2 Kota Bengkulu. Jenis penelitian yang dilaksanakan adalah Penelitian Tindakan Kelas (PTK) dengan teknik pengumpulan data melalui lembar observasi aktivitas. Subjek dalam penelitian ini adalah peserta didik kelas VII A SMP Negeri 2 Kota Bengkulu Semester Genap Tahun Ajaran 2017/2018 berjumlah 33 orang, teridiri dari 16 peserta didik laki-laki dan 17 peserta didik perempuan. Penelitian dilaksanakan dalam 3 siklus dari tanggal 26 maret 2018 sampai dengan 21 mei 2018. Hasil penelitian menunjukkan bahwa penerapan model pembelajaran inkuiri terbimbing dapat meningkatkan aktivitas belajar matematika peserta didik. Peningkatan aktivitas belajar matematika peserta didik dapat dilihat dari nilai rata-rata observasi peserta didik siklus I, II, dan III secara berturut-turut yaitu 27, 36.13, 38.63 dengan kriteria secara berturut-turut yaitu cukup aktif, aktif, aktif.
\end{abstract}

Kata Kunci: Aktivitas, Pembelajaran Inkuiri Terbimbing.

\begin{abstract}
ABSTRACK
This study aimed to improve mathematics learning outcpmes in rectangular and triangular materials by applying guided inquiry learning model. The type of this research is classroom action research with technique of collecting data by using learning observation sheet. Subjects of this research are students on VIIA class in SMP Negeri 2 Bengkulu City. The study was conducted in 3 cylces, which is one cycle consisted of four meetings and one final test. Implementation started on march 26th 2016 untill may 21th 2018. This research showed that implementation of guided inquiry learning improve the result of the students. The result of implementation guided inquiry learning model can be seeb from average score on test for first, second, and third cycle respectively which were $64,89,78,73,85,76$. The classical completeness in the first, second and third cycle which were 54,55\%, 75,76\% and 87,88\% respectively.
\end{abstract}

Key Terms: Learning activity, Guided Inquiry Learning

\section{PENDAHULUAN}

Pada pembelajaran matematika, seorang guru harus berusaha untuk mengurangi sifat abstrak dari suatu objek matematika sehingga memudahkan peserta didik menangkap pelajaran matematika di sekolah. Artinya, disesuaikan dengan perkembangan penalaran peserta didik, dengan mengusahakan agar "fakta", "konsep", “operasi" ataupun "prinsip" dalam matematika itu terlihat konkret (nyata). Menurut Soedjadi (2000:45) pembelajaran matematika terutama di jenjang SD dan SLTP penyajian topik matematika perlu diawali dengan langkah-langkah induktif, namun akhirnya tetap diarahkan agar peserta didik dapat berpikir secara deduktif. Artinya, penyajian matematika perlu dimulai dengan 
contoh-contoh, yaitu hal-hal yang khusus, selanjutnya secara bertahap menuju kepada suatu kesimpulan atau sifat yang umum.

Berbeda halnya dengan hasil wawancara dengan matematika SMP Negeri 2 Kota Bengkulu guru pada kegiatan pembelajaran lebih banyak kegiatannya menggunaka langkah-langkah induktif, sehingga terdapat beberapa permasalahan yang dihadapi guru, diantaranya (1) peserta didik masih bingung menggunakan konsep-konsep matematika karena peserta didik hanya menghapal konsep bukan memahaminya, (2) kurang optimalnya keterlibatan peserta didik dalam proses pembelajaran, sehingga aktivitas peserta didik menjadi rendah. Kondisi seperti ini mengakibatkan rendahnya aktivitas peserta didik sehingga diperlukan suatu usaha perbaikan dalam model pembelajaran matematika yang tepat dan inovatif untuk membantu peserta didik belajar secara aktif dalam proses belajar mengajar.

Kunandar dalam Shoimin (2014:85) menyatakan bahwa pembelajaran inkuiri merupakan kegiatan pembelajaran di mana peserta didik terlibat aktif dengan konsepkonsep dan prinsip-prinsip, dan guru mendorong peserta didik untuk memiliki pengalaman melalui percobaan yang membuat peserta didik menemukan konsep-konsep dari percobaan tersebut. Lebih lanjut, Gulo dalam Nurdin dan Adriantoni (2016:214) menyatakan inkuiri adalah kegiatan belajar yang melibatkan secara maksimal seluruh kemampuan peserta didik untuk mencari dan menyelidiki secara sistematis, kritis, logis, analitis, sehingga mereka dapat merumuskan sendiri penemuannya dengan percaya diri.

Langkah-langkah model pembelajaran inkuiri menurut Jacobsen, Eggen, dan Kauchak, Donald (2009: 243) dimulai dengan memberi peserta didik masalah-masalah yang nantinya menjadi fokus untuk aktivitas-aktivitas penelitian kelas. Dalam menyelesaikan masalah, peserta didik menghasilkan hipotesis atau solusi sementara untuk masalah tersebut, kemudian peserta didik mengumpulkan data yang relevan dengan hipotesis yang dibuat dan mengevaluasi data tersebut untuk mendapatkan kesimpulan.

Penjelasan selanjutnya langkah-langkah model pembelajaran inkuiri menurut Taufik dan Muhammadi (2011: 173), sebagai berikut :

(1) Orientasi merupakan langkah untuk membina suasana pembelajaran yang kondusif. Tahap-tahap orientasi: menjelaskan topik, tujuan, dan hasil belajar yang ingin dicapai oleh peserta didik, menjelaskan langkah-langkah kegiatan model inkuiri kepada peserta didik untuk mencapai tujuan, memberikan motivasi dengan menjelaskan pentingnya topik dan kegiatan belajar, (2) merumuskan masalah, guru memberikan peserta didik pada suatu persoalan atau permasalahan yang mengandung teka-teki. Proses mencari jawaban tersebut merupakan hal terpenting dalam pembelajaran inkuiri untuk memperoleh pengalaman melalui proses berpikir peserta didik, (3) merumuskan hipotesis, peserta didik diberikan berbagai pertanyaan yang dapat mendorong peserta didik untuk memberikan hipotesis dari permasalahan yang dibahas, (4) mengumpulkan data adalah proses mental yang sangat penting dalam pengembangan intelektual pembelajaran inkuiri, dikarenakan aktifitas yang dibutuhkan untuk menguji hipotesis yang diajukan, (5) menguji hipotesis adalah mengembangkan kemampuan berpikir rasional. Artinya, kebenaran jawaban yang tidak hanya berdasarkan argumentasi, tetapi didukung oleh data yang ditemukan dan dapat dipertanggungjawabkan, (6) merumuskan kesimpulan adalah proses mendeskripsikan temuan berdasarkan hasil pengujian hipotesis. Untuk mencapai kesimpulan yang akurat sebaiknya guru mampu menunjukkan kepada peserta didik mengenai data mana yang relevan.

Kegiatan pembelajaran di SMP Negeri 2 Kota Bengkulu menggunakan kurikulum 2013, yang menjadi pusat pembelajaran adalah peserta didik. Pada kurikulum 2013 terdapat pendekatan saintifik, yang memiliki komponen dalam proses pembelajaran yaitu, mengamati, 
menanya, mencoba, mengasosiasi dan mengkomunikasikan (Sani, 2014:54).

Pada penelitian ini, peneliti menggunakan aktivitas belajar melalui pembelajaran model inkuiri terbimbing. Pembelajaran inkuiri terbimbing merupakan pembelajaran yang menuntut peserta didik untuk melakukan serangkaian proses saintifik dari tahapan menetapkan masalah, merumuskan hipotesis, melakukan observasi, eksperimen, dan kegiatan penelitian sederhana, mengolah dan menganalisis data, menguji hipotesis, hingga tahapan membuat simpulan akhir atau simpulan umum serta mempersentasikannya (Abidin, 2014:151). Berikut ini uraian kegiatan yang terdapat pada LKPD dengan menggabungkan langkah-langkah kegiatan inkuiri terbimbing dengan pendekatan saintifik.

\section{Tabel 1 Perbandingan Model Inkuiri}

Terbimbing dengan Pendekatan Saintifik

\begin{tabular}{|c|c|c|}
\hline $\begin{array}{l}\text { Langkah- } \\
\text { Langkah } \\
\text { Model } \\
\text { Inkuiri }\end{array}$ & $\begin{array}{l}\text { Langkah- } \\
\text { Langkah } \\
\text { Pendekatan } \\
\text { Saintifik }\end{array}$ & $\begin{array}{l}\text { Langkah- } \\
\text { Langkah } \\
\text { Inkuiri } \\
\text { Terbimbing } \\
\text { dengan } \\
\text { Pendekatan } \\
\text { Saintifik }\end{array}$ \\
\hline $\begin{array}{l}\text { Orientasi } \\
\text { Peserta didik } \\
\text { mengamati } \\
\text { penjelasan } \\
\text { mengenai } \\
\text { topik, tujuan, } \\
\text { serta langkah- } \\
\text { langkah } \\
\text { model yang } \\
\text { digunakan. }\end{array}$ & $\begin{array}{l}\text { Mengamati } \\
\text { Peserta didik } \\
\text { melihat, } \\
\text { mengamati, } \\
\text { membaca, } \\
\text { mendengar, } \\
\text { dan } \\
\text { menyimak. }\end{array}$ & $\begin{array}{l}\text { Orientasi } \\
\text { (Mengamati) } \\
\text { Peserta didik } \\
\text { mengamati } \\
\text { penjelasan guru } \\
\text { mengenai topik, } \\
\text { tujuan dan } \\
\text { langkah- } \\
\text { langkah model } \\
\text { pembelajaran } \\
\text { yang digunakan. }\end{array}$ \\
\hline $\begin{array}{l}\text { Merumuska } \\
\text { n Masalah } \\
\text { Peserta didik } \\
\text { melalui } \\
\text { proses } \\
\text { mengamati } \\
\text { akan } \\
\text { dibimbing } \\
\text { dalam } \\
\text { menentukan } \\
\text { masalah }\end{array}$ & $\begin{array}{l}\text { Menanya } \\
\text { Peserta didik } \\
\text { mengajukan } \\
\text { pertanyaan } \\
\text { dari yang } \\
\text { faktual sampai } \\
\text { ke yang } \\
\text { bersifat } \\
\text { hipotesis; } \\
\text { diawali dengan } \\
\text { bimbingan }\end{array}$ & $\begin{array}{l}\text { Merumuskan } \\
\text { Masalah } \\
\text { (Menanya) } \\
\text { Peserta didik } \\
\text { diminta untuk } \\
\text { mengamati } \\
\text { permasalahan } \\
\text { dan dibimbing } \\
\text { dalam } \\
\text { menentukan } \\
\text { masalah }\end{array}$ \\
\hline
\end{tabular}

\begin{tabular}{|c|c|c|}
\hline $\begin{array}{l}\text { Langkah- } \\
\text { Langkah } \\
\text { Model } \\
\text { Inkuiri }\end{array}$ & $\begin{array}{l}\text { Langkah- } \\
\text { Langkah } \\
\text { Pendekatan } \\
\text { Saintifik }\end{array}$ & $\begin{array}{l}\text { Langkah- } \\
\text { Langkah } \\
\text { Inkuiri } \\
\text { Terbimbing } \\
\text { dengan } \\
\text { Pendekatan } \\
\text { Saintifik }\end{array}$ \\
\hline $\begin{array}{l}\text { (menanya) } \\
\text { untuk } \\
\text { mengarahkan } \\
\text { peserta didik } \\
\text { mencari } \\
\text { jawaban. }\end{array}$ & $\begin{array}{l}\text { guru sampai } \\
\text { dengan } \\
\text { mandiri. }\end{array}$ & $\begin{array}{l}\text { (menanya), } \\
\text { untuk } \\
\text { mengarahkan } \\
\text { peserta didik } \\
\text { mencari } \\
\text { jawaban. }\end{array}$ \\
\hline $\begin{array}{l}\text { Merumuska } \\
\text { n Hipotesis } \\
\text { Peserta didik } \\
\text { diharapkan } \\
\text { mampu } \\
\text { merumuskan } \\
\text { pertanyaan } \\
\text { atau } \\
\text { permasalahan } \\
\text {, serta melatih } \\
\text { membuat } \\
\text { hipotesis. }\end{array}$ & $\begin{array}{l}\text { Menanya } \\
\text { Peserta didik } \\
\text { mengajukan } \\
\text { pertanyaan } \\
\text { dari yang } \\
\text { faktual sampai } \\
\text { ke yang } \\
\text { bersifat } \\
\text { hipotesis; } \\
\text { diawali dengan } \\
\text { bimbingan } \\
\text { guru sampai } \\
\text { dengan } \\
\text { mandiri. }\end{array}$ & $\begin{array}{l}\text { Merumuskan } \\
\text { Hipotesis } \\
\text { (Menanya) } \\
\text { Guru } \\
\text { memberikan } \\
\text { pertanyaan- } \\
\text { pertanyaan yang } \\
\text { mendorong } \\
\text { peserta didik } \\
\text { untuk } \\
\text { memberikan } \\
\text { hipotesis dari } \\
\text { permasalahan } \\
\text { yang dibahas }\end{array}$ \\
\hline $\begin{array}{l}\text { Mengumpul } \\
\text { kan Data } \\
\text { Peserta didik } \\
\text { melakukan } \\
\text { percobaan } \\
\text { untuk } \\
\text { mendapatkan } \\
\text { data. }\end{array}$ & $\begin{array}{l}\text { Pengumpula- } \\
\text { n Data } \\
\text { Peserta didik } \\
\text { menentukan } \\
\text { data yang } \\
\text { diperlukan dari } \\
\text { pertanyaan } \\
\text { yang diajukan, } \\
\text { menentukan } \\
\text { sumber data } \\
\text { (benda, } \\
\text { dokumen, } \\
\text { buku, } \\
\text { eksperimen), } \\
\text { mengumpulka } \\
\text { n data. }\end{array}$ & $\begin{array}{l}\text { Mengumpulka } \\
\text { n Data } \\
\text { (Pengumpulan } \\
\text { Data) } \\
\text { Peserta didik } \\
\text { mengumpulkan } \\
\text { data } \\
\text { berdasarkan } \\
\text { pertanyaan yang } \\
\text { diajukan dan } \\
\text { menentukan } \\
\text { sumber data } \\
\text { (alat peraga dan } \\
\text { buku). }\end{array}$ \\
\hline $\begin{array}{l}\text { Menguji } \\
\text { Hipotesis } \\
\text { Peserta didik } \\
\text { menguji dari } \\
\text { hipotesis dan } \\
\text { pengumpulan } \\
\text { data }\end{array}$ & $\begin{array}{l}\text { Mengasosiasi } \\
\text { Peserta didik } \\
\text { menganalisis } \\
\text { data dalam } \\
\text { bentuk } \\
\text { membuat } \\
\text { kategori, } \\
\text { menentukan }\end{array}$ & $\begin{array}{l}\text { Menguji } \\
\text { Hipotesis } \\
\text { (Mengasosiasi) } \\
\text { Peserta didik } \\
\text { menguji dari } \\
\text { hpotesis dan } \\
\text { pengumpulan } \\
\text { data, untuk }\end{array}$ \\
\hline
\end{tabular}

Rahmi, Rusdi, Della

Penerapan Model Pembelajaran Inkuiri Terbimbing Untuk Meningkatkan Aktivitas Matematika

Peserta Didik Kelas VII SMP Negeri 2 Kota Bengkulu 


\begin{tabular}{|c|c|c|}
\hline $\begin{array}{l}\text { Langkah- } \\
\text { Langkah } \\
\text { Model } \\
\text { Inkuiri }\end{array}$ & $\begin{array}{l}\text { Langkah- } \\
\text { Langkah } \\
\text { Pendekatan } \\
\text { Saintifik }\end{array}$ & $\begin{array}{l}\text { Langkah- } \\
\text { Langkah } \\
\text { Inkuiri } \\
\text { Terbimbing } \\
\text { dengan } \\
\text { Pendekatan } \\
\text { Saintifik }\end{array}$ \\
\hline & $\begin{array}{l}\text { hubungan } \\
\text { data/kategori, } \\
\text { menyimpulkan } \\
\text { dari hasil } \\
\text { analisis data. }\end{array}$ & $\begin{array}{l}\text { menentukan } \\
\text { hubungan } \\
\text { data/kategori, } \\
\text { menyimpulkan } \\
\text { dari hasil } \\
\text { analisis data }\end{array}$ \\
\hline $\begin{array}{l}\text { Merumuska } \\
\text { n } \\
\text { Kesimpulan } \\
\text { Peserta didik } \\
\text { dibimbing } \\
\text { oleh guru } \\
\text { menarik } \\
\text { kesimpulan } \\
\text { dan } \\
\text { mengkomuni } \\
\text { kasikan }\end{array}$ & $\begin{array}{l}\text { Mengkomuni } \\
\text { kasikan } \\
\text { Peserta didik } \\
\text { menyampaikan } \\
\text { hasil } \\
\text { kesimpulan } \\
\text { dalam bentuk } \\
\text { lisan, tulisan, } \\
\text { diagram, } \\
\text { bagan, gambar } \\
\text { atau media } \\
\text { lainnya. }\end{array}$ & $\begin{array}{l}\text { Merumuskan } \\
\text { Kesimpulan } \\
\text { (Mengkomunik } \\
\text { asikan) } \\
\text { Peserta didik } \\
\text { dibimbing oleh } \\
\text { guru untuk } \\
\text { menarik } \\
\text { kesimpulan dan } \\
\text { mengkomunikas } \\
\text { ikannya dengan } \\
\text { mempersetasika } \\
\text { n ke depan } \\
\text { kelas. }\end{array}$ \\
\hline
\end{tabular}

(Sumber : Modifikasi Hosnan, 2016:39 dan Abidin, 2014:151)

\section{METODE PENELITIAN}

Jenis penelitian yang dilakukan adalah Penelitian Tindakan Kelas (PTK). Penelitian tindakan menurut Arikunto, Suhardjono dan Supardi (2015:41) memiliki empat tahapan yang dilakukan, yaitu (1) perencanaan (planning), pada tahap ini peneliti menyusun rancangan seperti menyiapkan rencana mengajar, bahan untuk kegiatan pembelajaran, (2) pelaksanaan tindakan (acting), yaitu peneliti memberikan penerapan pembelajaran dengan model atay dengan cara mengajar yang baru, (3) pengamatan (observing), yaitu aktivitas yang akan diamati pada kegiatan pembelajaran berlangsung dan untuk mengetahui kekurangan yang terdapat padaproses pembelajaran, (4) refleksi (reflection), tolak ukur terhadap keberhasilan atau kegagalan untuk mencapai tujuan penelitian. Keempat tahapan tersebut dilakukan untuk membentuk 1 siklus, yaitu suatu putaran beruntun yang kembali ke langkah semula. Ketika siklus selesai dilakukan pada tahap refleksi, maka hasil refleksi akan digunakan sebagai perencana pada siklus selanjutnya. Penelitian tindakan kelas ini dilakukan di SMP Negeri 2 Kota Bengkulu tahun ajaran 2017/2018. Subjek penelitian ini adalah peserta didik kelas VII A SMP Negeri 2 Kota Bengkulu yang berjumlah 32 peserta didik, dengan 16 peserta didik laki-laki dan 16 peserta didik perempuan. Subjek ini diperoleh dari data nilai ujian akhir semester ganjil matematika kelas VII SMP Negeri 2 Kota Bengkulu tahun ajaran 2017/2018 yang menunjukkan bahwa nilai rata-rata ujian akhir semester ganjil kelas VII A masih dibawah KKM yaitu 75 .

Instrumen yang digunakan dalam penelitian ini adalah lembar observasi. Lembar observasi aktivitas peserta didik yaitu berupa pengamatan terhadap aktivitas peserta didik selama proses belajar mengajar berlangsung, yang diisi oleh dua orang pengamat untuk mengetahui dan membantu pada penyusunan tindakan perbaikan terhadap yang harus dilakukan pada siklus selanjutnya. Setiap butir pada lembar observasi diberikan kriteria penilaian, yaitu :

Tabel 2 Kriteria Penilaian untuk Lembar Observasi Aktivitas Peserta Didik

\begin{tabular}{|c|c|c|}
\hline $\begin{array}{c}\text { Kriteria } \\
\text { Penilaian }\end{array}$ & Notasi & Skor \\
\hline Kurang & K & 1 \\
\hline Cukup & C & 2 \\
\hline Baik & B & 3 \\
\hline
\end{tabular}

Kisaran nilai aktivitas belajar peserta didik:

Kisaran nilai untuk tiap kriteria

$$
=\frac{\text { Skor Tertinggi }- \text { Skor Terendah }+1}{\text { Jumlah Kriteria }}
$$

Keterangan :

Skor tertinggi $=$ jumlah butir observasi $\mathrm{x}$ skor tertinggi tiap butir observasi.

Skor terendah $=$ jumlah butir observasi $\mathrm{x}$ skor terendah tiap butir observasi. 
Observasi aktivitas peserta didik dilakukan oleh dua orang pengamat, maka nilai rata-rata skor dapat diolah dengan menggunakan rumus berikut ini:

$$
\text { nilai skor }(x)=\frac{P 1+P 2}{2}
$$

(Sudjana, 2016:109)

Pada penelitian ini, jumlah butir aktivitas peserta didik adalah 13 , sehingga kisaran nilai untuk tiap kriteria adalah 9, sebagai berikut:

$$
\begin{aligned}
& =\frac{\text { Skor Tertinggi }- \text { Skor Terendah }+1}{\text { Jumlah Kriteria }} \\
& =\frac{39-13+1}{3} \\
& =\frac{27}{3} \\
& =9
\end{aligned}
$$

Sehingga, diperoleh kisaran skor untuk lembar observasi peserta didik adalah sebagai berikut:

Tabel 3 Kisaran Skor Lembar Observasi Aktivitas Peserta Didik

\begin{tabular}{|c|c|}
\hline Kriteria Penilaian & Kisaran Skor \\
\hline Kurang Aktif & $13 \leq \mathrm{x} \leq 21$ \\
\hline Cukup Aktif & $21<\mathrm{x} \leq 30$ \\
\hline Aktif & $30<\mathrm{x} \leq 39$ \\
\hline
\end{tabular}

Keterangan :

$\mathrm{x}=$ Rata-rata skor hasil observasi

\section{HASIL DAN PEMBAHASAN Hasil}

Penelitian dilaksanakan pada semester genap tahun pelajaran 2017/2018, yaitu pada tanggal 26 Maret dan selesai pada tanggal 21 Mei 2018. Pelaksanaan tindakan tiap siklus dilakukan sesuai langkah-langkah model Pembelajaran Inkuiri Terbimbing dan disesuaikan dengan Rencana Pelaksanaan Pembelajaran (RPP) yang telah dibuat. Selama pembelajaran berlangsung dua orang pengamat menggunakan instrumen lembar observasi dengan 13 aspek yang akan diamati dan dinilai, yaitu (1) peserta didik mendengarkan peneliti menjelaskan langkah-langkah kegiatan pembelajaran untuk mencapai tujuan pembelajaran, (2) peserta didik membaca permasalahan yang diberikan oleh guru pada LKPD (3) peserta didik bertanya terhadap materi atau permasalahan yang belum dipahami, (4) peserta didik mampu merumuskan masalah dari suatu permasalahan yang diberikan, (5) peserta didik mendiskusikan dan memberikan pendapat atau ide dalam penyelesaian masalah secara berkelompok, (6) peserta didik menuliskan jawaban sementara (hipotesis) dari suatu permasalahan yang diberikan, (7) peserta didik menggambar bangun datar segiempat dan segitiga, (8) peserta didik menentukan panjang sisi dan besar sudut, (9) peserta didik menguji hipotesis yang telah dibuat berdasarkan data atau informasi yang telah dikumpulkan, (10) peserta didik membuat kesimpulan dari penyelesaian masalah yang ada, (11) peserta didik mempresentasikan hasil pengerjaan LKPD dengan percaya diri, (12) peserta didik mengemukakan gagasan dan pendapat atau ide dari penjelasan atau pertanyaan yang disampaikan oleh guru atau teman sekelas, (13) peserta didik memperhatikan penjelasan guru mengenai kesimpulan pembelajaran. Berikut ini aktivitas peserta didik yang diamati oleh pengamat dengan menerapkan pembelajaran inkuri terbimbing pada saat kegiatan pembelajaran berlangsung:

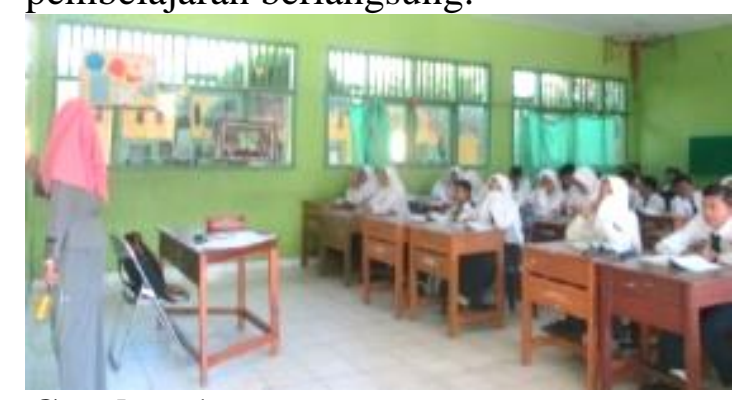

\section{Gambar 1. Aktivitas Peserta Didik Pada Tahap Orientasi}

Pada gambar 1 menunjukkan bahwa
peserta didik mendengarkan dan
memperhatikan dengan baik penjelasan peneliti
mengenai topik, tujuan pembelajaran dan
langkah-langkah yang akan dilakukan untuk
menyelesaikan setiap kegiatan yang diberikan
pada LKPD.




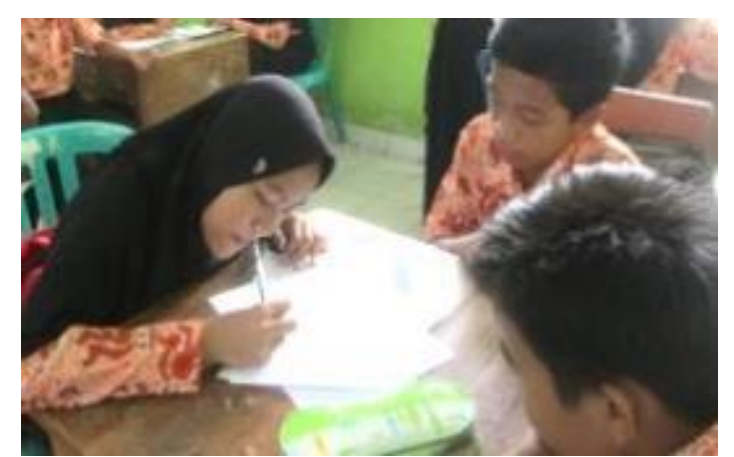

Gambar 2. Aktivitas Peserta Didik Pada Tahap Merumuskan Masalah

Peserta didik pada gambar 2 melakukan aktivitas pada tahap merumuskan masalah, terlihat peserta didik mengarahkan anggotanya untuk menjawab pertanyaan-pertanyaan terbimbing pada LKPD yang diberikan.

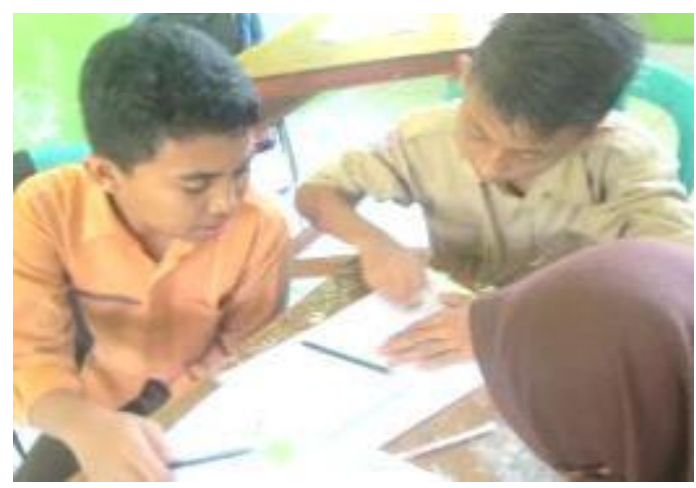

Gambar 3. Aktivitas Peserta Didik Pada Tahap MerumuskanHipotesis

Terlihat pada gambar 3, kelompok yang sedang berdiskusi dan memberikan pendapat untuk menuliskan jawaban sementara pada LKPD.

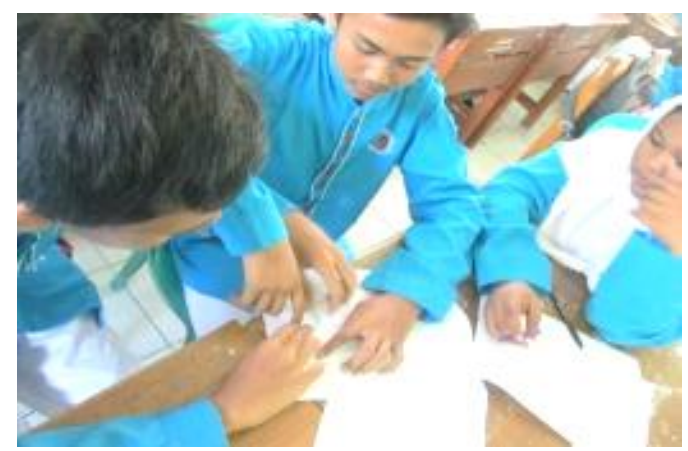

Gambar 4. Aktivitas Peserta Didik Pada Tahap Mengumpulkan Data dan Menguji Hipotesis
Pada gambar 4 menunjukkan bahwa adanya diskusi antar anggota kelompok untuk menyelesaikan setiap kegiatan yang ada pada LKPD. Pada tahap kegiatan ini, peneliti memberikan alat perga sesuai dengan sub materi yang dipelajari agar aktivitas peserta didik meningkat, yaitu alat peraga berbagai bangun datar segiempat dan segitiga, dan tali kur utnuk menghitung keliling bangun datar segiempat dan segitiga

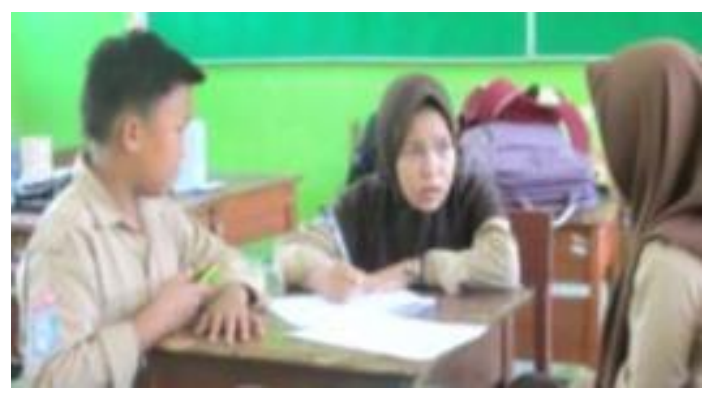

\section{Gambar 5. Aktivitas Peserta Didik Pada Tahap Merumuskan Kesimpulan}

Peserta didik pada gambar 5 menunjukkan bahwa mereka mendiskusikan hasil kesimpulan yang telah diperoleh pada tahap mengumpulkan data dan menguji hipotesis. Pada tahap ini peneliti membantu peserta didik dengan memberikan arahan untuk menyimpulkan pembelajaran yang telah dilaksanakan dengan baik.

Pada aktivitas 11, peserta didik mempersentasikan hasil diskusi kelompoknya, yaitu sebagai berikut:

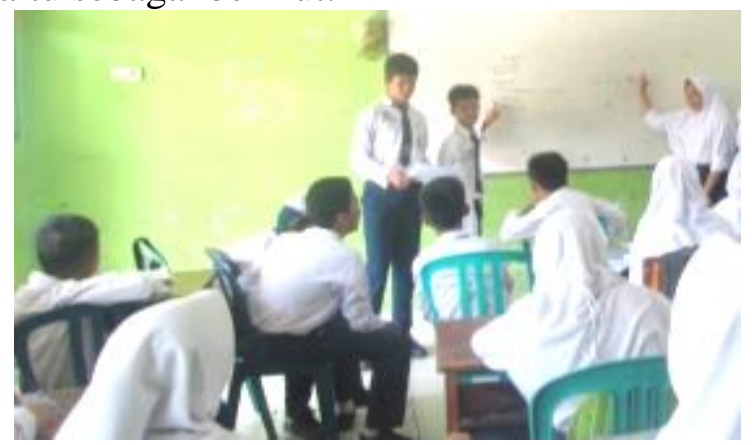

Gambar 6. Peserta didik Persentasi Hasil Diskusi Kelompok

Pada gambar 6, memperlihatkan bahwa peserta didik menjelaskan hasil diskusi kelompoknya dan memberikan penjelasan terhadap peserta didik

Rahmi, Rusdi, Della

Penerapan Model Pembelajaran Inkuiri Terbimbing Untuk Meningkatkan Aktivitas Matematika Peserta Didik Kelas VII SMP Negeri 2 Kota Bengkulu 
lainnya yag memberika tanggapan atau pertanyaan kepada kelompok penyaji.

\section{Pembahasan}

Pengamatan pada penelitian ini bertujuan untuk mengetahui aktivitas peserta didik pada saat penerapan model pembelajaran inkuiri terbimbing.

Lembar observasi aktivitas peserta didik yang digunakan untuk mengukur keaktifan peserta didik, terdiri dari 8 aspek pegamatan aktivitas yang meliputi listening activities, visual activities, oral activities, writing activities, drawing activities, motor activities, mental acrivities, dan emotional activities. Berikut ini tabel hasil data pengamatan yang dilakukan oleh dua orang pengamat:

Tabel 4. Rata-rata Skor Aktivitas Peserta Didik Siklus I, II, dan III

\begin{tabular}{|l|c|c|c|}
\hline Siklus & $\begin{array}{c}\text { Rata-Rata } \\
\text { Skor }\end{array}$ & Kriteria & Keterangan \\
\hline I & 27 & Cukup Aktif & Belum Berhasil \\
\hline II & 36,13 & Aktif & Berhasil \\
\hline III & 38,63 & Aktif & Berhasil \\
\hline
\end{tabular}

Pada gambar 1 menunjukkan bahwa hasil pengamatan aktivitas peserta didik pada setiap siklus meningkat. Hal ini dikarenakan peneliti memberikan tindakan perbaikan pada siklus selanjutnya, yaitu pada siklus I meperbaiki LKPD dengan memebrikan inovasi yang lebih menarik dan singkat dari siklus sebelumnya dengan mengubah bentuk bentuk page layout dari portrait menjadi landscape dan menyatukan tahap kegiatan mengumpulkan data dan menguji hipotesis. Pada setiap tahap kegiatan peneliti berkeliling untuk mengontrol dan membimbing peserta didik dan menyanyakan kepada peserta didik mengenai materi atau permasalah apa yang masih dianggap sulit.

Selanjutnya, analisis berdasarkan data hasil pengamatan perkembangan aktivitas peserta didik pada setiap siklus, terdapat pada gambar berikut ini:

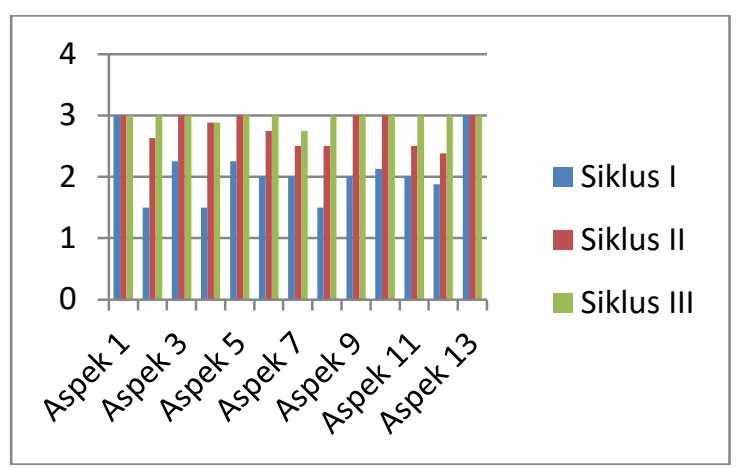

\section{Gambar 7. Perkembangan Aktivitas Peserta Didik per aspek tiap Siklus}

Pada aktivitas pembelajaran siklus I peserta didik dibentuk dalam 8 kelompok yang terdiri 4 atau 5 orang yang dipilih secara heterogen berdasarkan jenis kelamin dan nilai UAS semester ganjil, pada siklus II peserta didik dibentuk dalam 11 kelompok yang terdiri dari 3 orang peserta didik secara heterogen berdasarkan nilai tes akhir siklus. Langkah pertama pembelajaran inkuiri terbimbing adalah orientasi, pada penelitian ini peserta didik mengamati penjelasan guru mengenai tofik, tujuan dan langkah-langkah pembelajaran

Langkah kedua merumuskan masalah, setelah mengamati penjelasan guru mengenai langkah-langkah kegiatan yang akan dilakukan, peserta didik menjawab rumusan masalah pada Lembar Kerja Peserta Didik (LKPD)

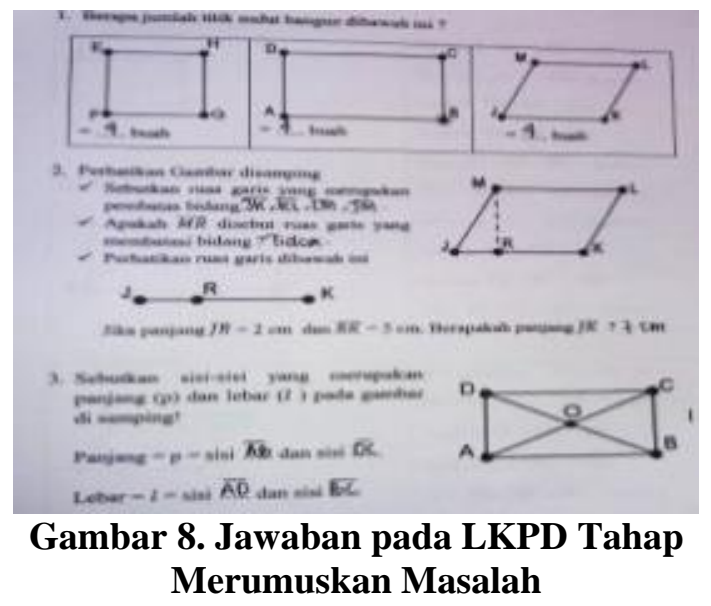

Dari gambar di atas, terlihat peserta didik menjawab pertanyaan-pertanyaan yang membimbing, yaitu peneliti mengarahkan peserta didik menjawab dari hasil pengamatan 
bangun datar yang diberikan pada LKPD. Pada langkah ini peneliti menuntuk peserta didik untuk memberikan hipotesis (jawaban sementara).

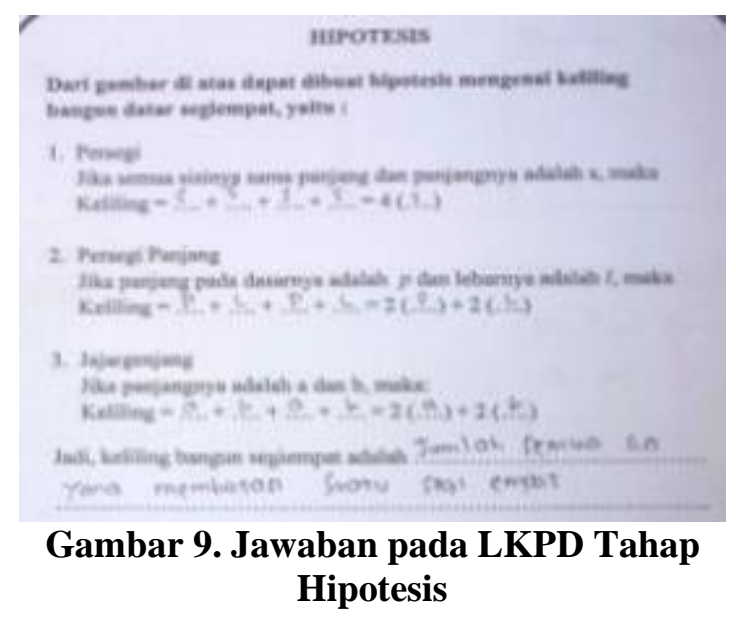

Gambar 3 merupakan salah satu jawaban kelompok pada materi keliling segiempat (persegi, persegipanjang, dan jajargenjang). Setelah peserta didik melengkapi pertanyaanpertanyaan pada tabel dan peserta didik membuat hipotesis tentang pengertian keliling bangun datar segiempat.

Tahap ketiga adalah mengumpulkan data dengan memberikan langkah-langkah atau pertanyaan-pertanyaan yang terkait pada materi yang sedang dipelajari. Berikut ini gambar kegiatan mengumpulkan data pada pertemuan 4 tentang menemukan luas bangun trapesium siku-siku.

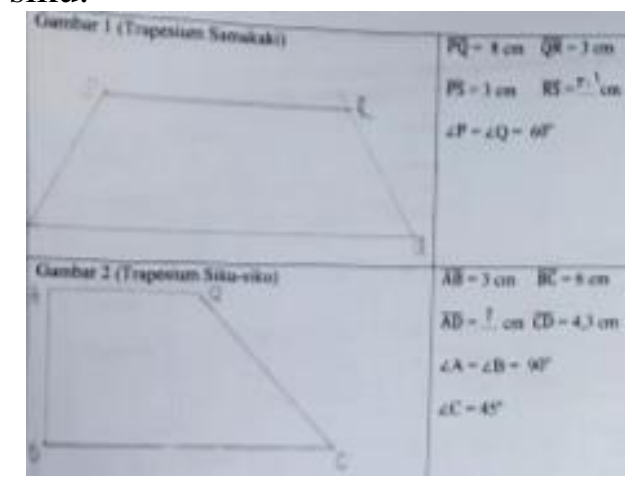

\section{Gambar 10. Jawaban pada LKPD Tahap Mengumpulkan Data dan Menguji Hipotesis}

Peserta didik menjawab pertanyaan-pertanyaan berdasarkan gambar yang diberikan pad LKPD dan peserta didik membandingkan ketiga gambar yang diberikan untuk mendapatkan konsep yang diberikan dengan baik. Selanjutnya pada tahap keempat peserta didik menguji hipotesis yang dibuat pada tabel "panjang tali = keliling" dengan menggunakan alat peraga tali kur yang telah diberikan sebelumnya pada saat pembagian LKPD.

Pada tahap keenam merumuskan kesimpulan. Peserta didik menghubungkan informasi-informasi yang telah diperoleh pada tahap mengumpulkan data dan menguji hipotesis. Berikut gambar jawaban salah satu kelompok.

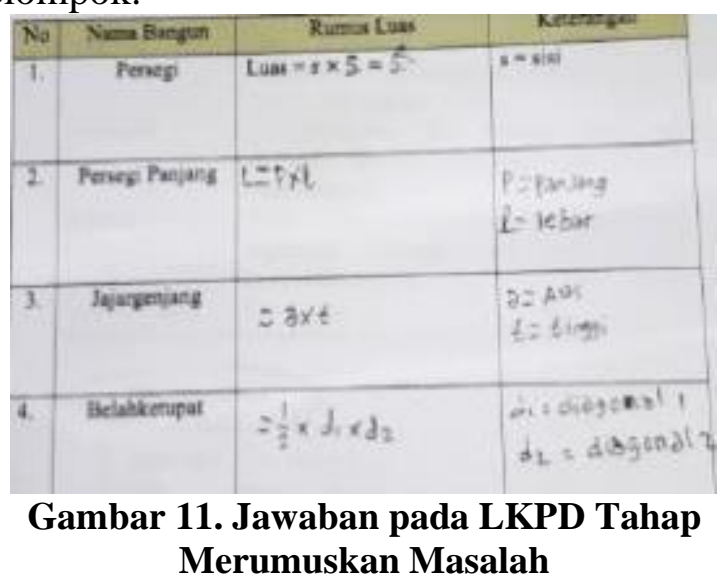

Hasil pengamatan oleh dua orang pengamat pada siklus I, siklus II, dan siklus III menunjukkan bahwa penerapan pembelajaran model inkuiri terbimbing dapat meningkatkan aktivitas belajar peserta didik, dengan rata-rata skor pada siklus III adalah 38,63. Hal ini dikarenakan dengan menerapkan model pembelajaran inkuiri terbimbing peserta didik memperoleh pengetahuan bukan langsung dari guru melainkan, peserta didik membangun sendiri pengetahuan yang akan dicarinya, sehingga memastikan keterlibatan peserta didik secara aktif selama proses pembelajaran.

\section{PENUTUP \\ Kesimpulan}

Adapun tindakan yang dilakukan oleh peneliti untuk meningkatkan aktivitas peserta didik, yaitu (1) mengurangi anggota kelompok yang awalnya terdiri dari 4-5 orang peserta 
didik menjadi 3 orang peserta didik dalam satu kelompok, (2) peneliti mengarahkan peserta didik dengan memberikan umpan balik sesuai dengan apa yang diketahui dan ditanyakan pada suatu permasalahan yang terdapat pada LKPD atau pada materi yang sedang dipelajari, (3) memberikan inovasi yang lebih menarik pada LKPD, agar peserta didik pada aktivitas membaca lebih meningkat, (4) memilih peserta didik secara acak jika tidak ada peserta didik yang memberikan tanggapan terhadap kesimpulan pembelajaran, namun peneliti tetap memberikan arahan kepada peserta didik untuk memberikan tanggapan dari kesimpulan yang telah dipelajari, (5) memberikan pengutan terhadap hasil diskusi yang telah disampaikan oleh peserta didik, (6) peserta didik yang tidak mengikuti pembelajaran dengan baik, maka peneliti akan memberikan teguran, (7) pada kegiatan persentasi hasil diskusi kelompok ke depan kelas, peneliti memberikan kesempatan untuk yang ingin mempersentasikan. Jika tidak ada, peneliti akan menunjuk secara acak kelompok yang akan mempersentasikan hasil diskusi kelompoknya, (8) peneliti memberikan motivasi agar peserta didik lebih terlibat aktif dalam kegiatan pembelajaran dan memberikan applause kepada peserta didik yang mempersentasikan hasil diskusi kelompoknya.

Berdasarkan hasil penelitian yang telah dilakukan diperoleh kesimpulan bahwa penerapan model pembelajaran inkuri terbimbing dapat meningkatkan aktivitas peserta didik. Aktivitas belajar peserta didik dari siklus I, siklus II, dan siklus III secara berturut-turut adalah 27, 36.13, dan 38.64 dengan kriteria cukup aktif, aktif, dan aktif.

\section{Saran}

Berdasarkan penelitian yang telah dilakukan peneliti, maka saran yang dapat diberikan oleh peneliti adalah setiap kegiatan dan tahap dalam pembelajaran diberikan petunjuk yang lengkap dan jelas agar peserta didik tidak selalu bertanya kepada guru tentang apa yang harus dilakukan serta dapat mengoptimalkan waktu yang digunakan.

\section{DAFTAR PUSTAKA}

Abidin, Yunus. 2016.Desain Sistem Pembelajaran dalam Konteks Kurikulum 2013. Bandung:PT Refika Aditama.

Arikunto, Suharsimi, Suhardjono, dan Supardi. 2015. Penelitian Tindakan kelas Edisi Revisi. Jakarta: Bumi aksara.

Hendriana, Heris dan Utari Soemarmo. 2017. Penilaian Pembelajaran Matematika. Bandung: PT Refika Aditama.

Hosnan. 2014. Pendekatan Saintifik dan Kontekstual dalam Pembelajaran Abad 21. Bogor: Ghalia Indonesia.

Jacobsen, David LA, Paul Eggen dan Donald Kauchak. 2009. Methods For Teaching. Yogyakarta: Pustaka Belajar.

Rusman. 2014. Model-Model Pembelajaran Mengembangkan Profesionalisme Guru Edisi Kedua. Jakarta: PT RajaGrafindo Persada.

Soedjadi. 2000. Kiat Pendidikan Matematika di Indonesia Konstansi Keadaan Masa Kini Menuju Harapan Masa Depan. Jakarta: Direktorat Jendral Pendidikan Tinggi Departemen Pendidikan Nasional.

Sudijono, Anas. 2008. Pengantar Evaluasi Penddidikan. Jakarta: Raja Grafindo Persada.

Sani, Ridwan Abdullah. 2014. Pembelajaran Saintifik Untuk Implementasi Kurikulum 2013. Jakarta: PT Bumi Aksara.

Suprijono, Agus. 2014. Cooperative Learning. Yogyakarta: Pustaka Belajar.

Suherman, Erman dan Udin S. Winataputra. 1992/1993. Strategi Belajar Mengajar matematika. Jakarta: Universitas terbuka, Departemen Pendidikan dan Kebudayaan.

Taufik, Taufina dan Muhammadi. 2009. Mozaik Pembelajaran Inovatif. Padang: Sukabina Press. 